\title{
EXAMPLES OF GOOD PRACTICE IN THE FIELD OF EARLY AND INITIAL LEARNING OF FOREIGN LANGUAGES IN FORMAL EDUCATION
}

\begin{abstract}
Summary
The beginning of the 21 st century brings innovations in linguistic planning and programming within the Europe, placing on the foreground the need to master another two foreign languages in addition to the mother tongue. It is not easy to accomplish such a goal, unless the process of learning foreign languages starts in early childhood. This paper reports on a part of the results of a two-year empirical study conducted by implementation of the case study method, on a sample of sixty students of primary school. The sample consists of students of the first and the second grade (the first year of learning the second foreign language), i.e. the second and the third grade (the second year of learning the second foreign language). By measuring lexical competence that is crucial for determining the efficiency of the process of early learning of two foreign languages in formal education, we make conclusions on the functionality of introducing two foreign languages into the first educational cycle. We determine the differences between older and younger students and the amount of their levelling after longer exposure to a new linguistic input. In addition, lexical units are distributed within domains according to the extent to which students were able to more easily acquire the lexicon that is the subject of their interest.
\end{abstract}

Key words: students, age, early learning, second foreign language, lexical competence.

\section{Introduction}

The idea of the united Europe has inevitably brought innovations in the field of linguistic policy. Growing openness of markets among the member states and new strategies of development on global level have

*aleksandra-s@eunet.rs 
resulted in the need to remove linguistic barriers between the Europeans. There is a determination to give equal chances to all languages, without their classification as great and small ones. It is not easy to accomplish such a goal without starting to learn (i.e. acquire) foreign languages in the early childhood. In this regard, the Council of Europe has opened the issue of multilingualism from the early age, pleading for adopting at least two languages other than the mother tongue. In this manner, the early learning/ acquisition of foreign languages becomes a common theme both for the research within the linguistic community to which the language belongs but also outside of it.

During the nineties of the $20^{\text {th }}$ century, both in Europe and in Serbia the situation was moving in the direction of the implementation of multilingual model. "Selection and the number of foreign languages is in direct correlation with ideological and academic attitudes of creators of different politics of foreign language education" (Filipović 2009, 68). The attempt to reform the educational system in Serbia lasted from 2000 until 2003. Model of the reformation was based on the early learning of the first foreign language (hereinafter referred to as FL1), even from 6-7 years of age, i.e. the first grade of primary school, introducing the second foreign language (FL2) from the fourth grade and with the possibility to attend optional education even of the third foreign language (FL3) (Vučo 2005, 436). The reformation has failed in some of the propositions and even today FL1 is studied from the first grade, i.e. from the seventh year of age, while FL2 is studied from the fifth grade, i.e. from the tenth/eleventh year of age, which may be rather critical period for adopting a language at all levels equally (especially in the field of phonetics).

In this paper, we present a part of the results of the research that represents an advance with regard to the previous research in the region. Namely, the goals like "functionality of introducing the second foreign language in the first cycle of primary education system", as well as "critical retrospection to existing foreign language education and guides for improvement" will be presented by checking two hypotheses. The first one refers to the role of lexical competence in establishing success in the process of early learning two foreign languages in formal education, while the second one explores if the length of exposure to the second foreign language levels differences in achievements between older and younger students. 


\section{Foreign Language Learning in Serbia at the End of the 20th and the Beginning of the 21st Century}

Tendency of accepting the English language as the most popular FL in Serbian primary schools continues in the Republic of Serbia (Filipović, Vučo, Djurić 2007, 234). According to the data obtained from the Ministry of Education, Science and Technological Development (MESTD) of the Republic of Serbia, the situation in primary schools in 2009 was the following: 399,767 students (89.8\%) learned the English language as FL1 in the first educational cycle in the first four grades; 18,994 students (4.3\%) learned the German language; 16,186 students (3.6\%) learned the French language; 9,270 students (2\%) learned the Russian language; 570 students $(0.12 \%)$ learned the Italian language and 33 students (one class, i.e. $0.007 \%$ ) learned the Spanish language of total number of students between 7 and 11 years of age. The total number of students in the first educational cycle in 2009 was 445,270 (see Graph 1).

Graph 1. FL1 in the first educational cycle, from the first to the fourth grade of primary school.

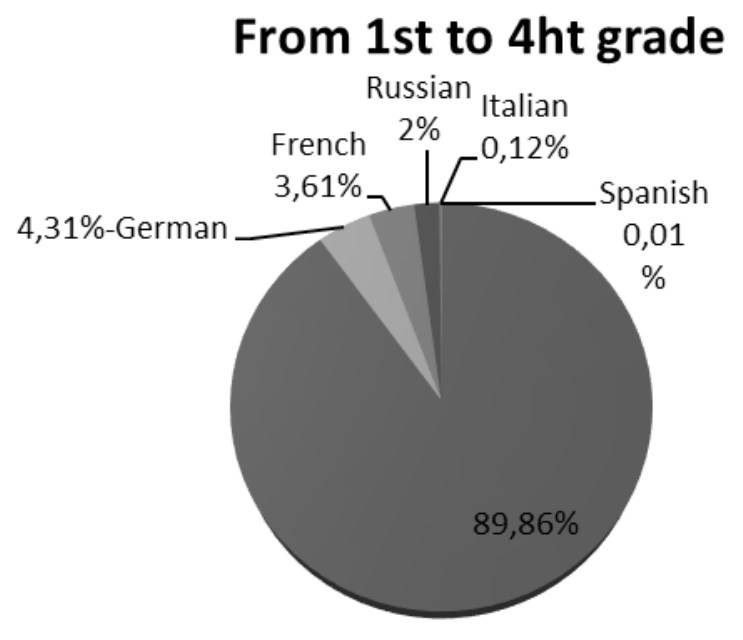

In the second educational cycle, i.e. from the $5^{\text {th }}$ to the $8^{\text {th }}$ grade, when learning of FL2 starts, the situation was the following according 
to the mentioned statistics: 180,440 students $(48.3 \%)$ of the total number of students in the second educational cycle learned the English language as FL2; 67,997 students (18.18\%) learned the German language; 63,248 students (16.9\%) learned the French language; 51,861 students (13.9\%) learned the Russian language; 7,307 students (1.9\%) learned the Italian language and 3,061 students $(0.8 \%)$ learned the Spanish language. The total number of students in the second educational cycle in 2009 was 373 , 914 (see Graph 2).

Graph 2. FL2 in the second educational cycle, from the fifth to the eight grade of primary school.

\section{From 5th to 8th grade}

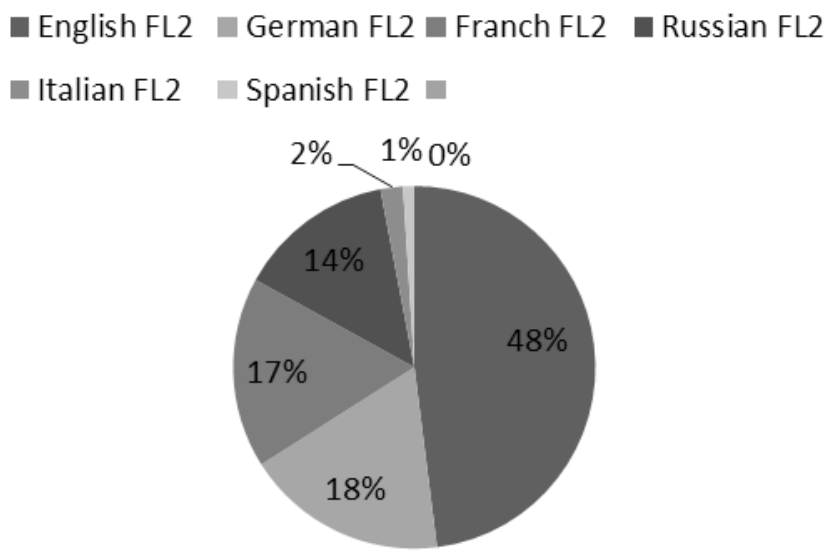

It is possible to conclude from the presented that in $2009,819,184$ students in Serbia attended compulsory primary education; $70.1 \%$ of that number attended classes of the English language either as FL1 or as FL2; $10.6 \%$ the German; 9.7\% the French; $7.5 \%$ the Russian; 0.97\% the Italian and $0.38 \%$ the Spanish language.

There is no doubt that Serbia opted for internationalisation of education in general (by accepting the Bologna Process); therefore, the concept of introducing learning several languages is in accordance with that idea. Such educational policy is beneficial and is based on the concept of exchange of knowledge. Early learning of foreign languages is the path for 
accomplishing that exchange. However, early learning of the English language in almost all primary schools in Serbia from the first grade does not necessarily promote the policy of plurilingualism.

Bugarski (2003) has a similar attitude indicating that the English language today has reached the phase of such a prevalence in many countries, including Serbia, that it is impossible to speak in the traditional categories of mother tongue and foreign language, but "a new concept, whose only representative will be the English language" must be introduced. Bugarski proposes the term "additional language" — "as the most adequate technical term covering the mentioned meaning", which emphasizes the prevalence of the English language in the countries in which it has not the status of the official language, but is widely used, so that the term "foreign" has become "too narrow" for it (Bugarski 2003, 8-9).

The possibility for learning several different FL represents both cognitive and communicative advantage for younger students. By interacting with several different cultures and thereby several different languages, younger students are smoothly introduced with a foreign language that they will continue to study in more depth later on together with their mother tongue and FL1. Simultaneously, the results of a number of research have shown that simultaneous presence of two linguistic modalities, in an encouraging atmosphere, is the source for further improvement and personal benefit of students (Šuvakovic 2014, 313).

\section{Research on Early Learning of Two Foreign Languages in the First Educational Cycle}

A part of the research presented in this paper was completed within the project realized in cooperation of the Faculty of Philology of the University in Belgrade and the Primary School "Jovan Ducic" from New Belgrade. Classes of the Italian language as the second foreign language were organized twice a week for 45 minutes during the first year of the research $2011 / 2012$ with students of the first and the second grade, i.e. three times a week for 45 minutes during the second year of the research 2012/2013 with students of the second and the third grade. With the parents' consent, students attended the classes of Italian as FL2 during their after-school care. 
A total number of students in both classes was 60 and they were divided into four groups (15 students in each group), two groups for each grade.

During the first year of the research, in the 2011/2012, students of the first grade had just started with learning how to read and write in Cyrillic alphabet, while the students of the second grade learned the Latin alphabet from the second semester. According to the capabilities of students, we had the task to choose approaches and methods for an easier implementation of ludic activities. In addition to psycho-affective and psycho-motoric approach, the basis of the educational process was humanistic-affective approach. In line with the research results (Cushman and Cowan 2010, 86-88), collaborative spirit and cooperation were cherished in classroom, both between peers and between them and their FL2 teacher. Relaxed and friendly atmosphere led either to non-activation of affective filter or to its very poor activation, leading to its complete loss over time.

Ludic activities were the pole of the complete educational process. Students were learning through play and interaction with their peers. Interaction with other children and certain linguistic routines (greetings, introductions, giving thanks) represented a base-line for verbal production. Various activities were used in teaching: a) memory game: puzzles, learning songs, singing; b) drill games: dialogue, chains ("deaf telephones"), filling-in sentence; c) symbolic games: dramatization with puppets, masks, performing; d) table games: dominoes, memory, tombola, bingo; e) action games where children have already learned in FL the games with familiar rules from L1, e.g. "Ringe Ringe Raja” or 'Blind Man's Bluff'. They provide a possibility to connect the target language (TL), in our case the second foreign language (FL2), with mother tongue in a natural and authentic manner in a social-cultural context through the interaction with the peers. The communicative approach in which the TL is a means of communication and promotion of students' verbal production imply simultaneous acquisition of knowledge about foreign countries and their culture, as well as about specific atmosphere that is transferred during the educational process (Vučo 2013, 374). The acquisition of ideas about the children in TL country and their play, as well as their connecting with their own tradition and culture at an early age, may influence the students' motivation to a great extent (Vučo 2010, 53-61).

Different techniques were used alternatively, depending on the skill we were trying to improve in the class: a) for improving receptive skills: 
understanding (cloze, transcodification from word to image, affiliation); b) techniques for developing productive skills: verbal production (transcoding from image to word); c) techniques for development of integrated skills: (dialogue, dramatization, role taking, simulation, Picasso dictation, etc.).

Since the early learning of FL is a process that cannot be compared with any other school subject, precisely due to the experience a child has gained while acquiring the mother tongue (L1), the question is why not offering teaching of an elective FL2 in the first educational cycle together with FL1, as an optional subject? Such a concept of linguistic policy in Serbia would improve creation of multilingualism in our society, having effects also in the field of improving interculturalism of students as the bearers of the society in the future, overcoming ethnic and other stereotypes that exist in every society.

\section{Results of Successful Adoption of Lexical and Simple Morpho- syntactic Structures of the Second Foreign Language}

\section{Structure of the examinees}

Sixty students of the first and the second grade participated in the research, age seven and eight. A half of the total number were boys, another half were girls.

Twenty-eight students from the first grade participated in the research - 13 girls and 15 boys, while the number of participants in the second grade was slightly larger-32 students (17 girls and 15 boys).

\section{Experience in learning foreign languages before going to school}

Active participants in the research were also parents of younger students. Through the analysis of their answers from the questionnaire, we found out that all the examined students originated from monolingual families speaking Serbian, as well as that $86 \%$ of students had learned foreign language before going to school; it should be noted, however, that in 100\% of cases the first foreign language the students had faced was the English language. Only five students of the second grade and three students of the 
first grade did not learn foreign language before going to school. Therefore, early learning of FL1 and FL2 overlapped in the case of these three students. Out of the total number of those who had learned foreign language before going to school, $78.0 \%$ of them had learned foreign language in the pre-school educational cycle, $12 \%$ in private schools, while $10 \%$ of the students had private lessons of the English language.

Testing productive skills during the first year of learning the Italian language as FL2

With the aim to confirm the established hypotheses, the first out of the two researches was performed at the end of the 2011/2012 school year regarding the adoption of vocabulary, both active and passive, i.e. receptive, so-called Lexical test.

The vocabulary items were divided into thirteen domains according to the fields to which they associate. Twenty-seven students of the first grade and thirty-one student of the second grade participated in the test (see Graph 3).

Graph 3. Distribution of active, receptive knowledge, as well as the absence of knowledge of lexical units on test 2011/2012.

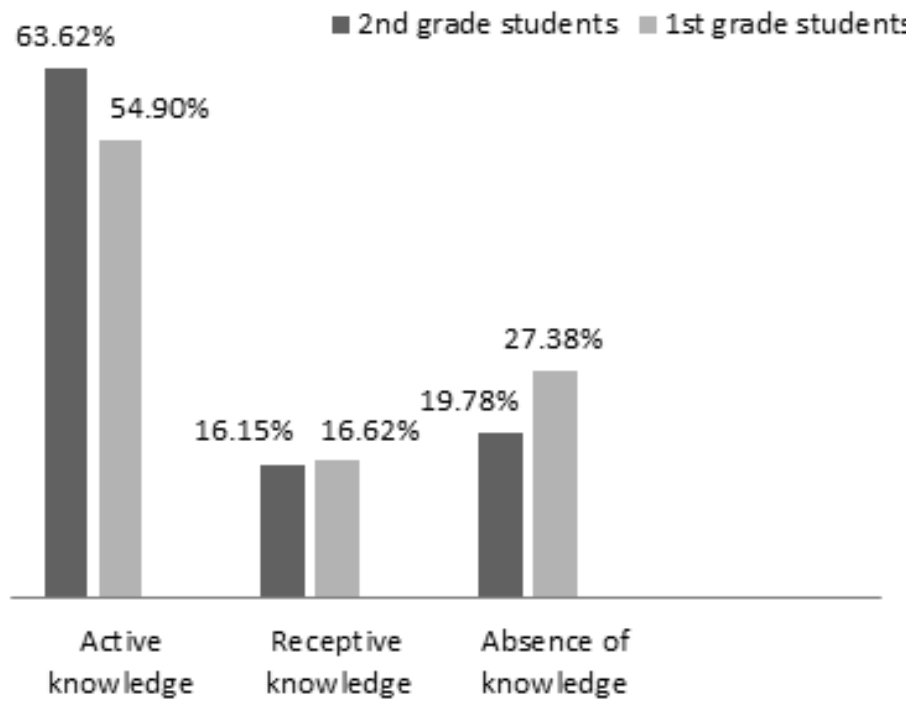


Total percentage for active knowledge of 104 items for second grade students is $63.62 \%$, for receptive knowledge $16.15 \%$ and the absence of knowledge $19.78 \%$.

Total percentage for active knowledge of 104 items for first grade students is $54.9 \%$, for receptive knowledge $16.62 \%$ and the absence of knowledge $27.38 \%$.

On the basis of the obtained results we conclude that the students of the second grade accomplished better results in active knowledge in comparison with the first grade students for 8.72. The students of the first grade accomplished better results in comparison with the older students regarding the receptive knowledge of vocabulary at $0.47 \%$. Absolute absence of both active and receptive knowledge of vocabulary is lower for the second grade students at $7.6 \%$.

Identical test was conducted during the next 2012/2013 school year. It should be pointed out that during the second year of the research the number of classes was increased from two to three per week, in accordance with the expressed desire of the younger students. Therefore, the results of the Lexical test were in direct correlation with the greater exposure to the TL, confirming Brown's research on frequency (Brown 1994).

Graph 4. Distribution of active, receptive knowledge as well as the absence of knowledge of lexical items in test 2012/2013.

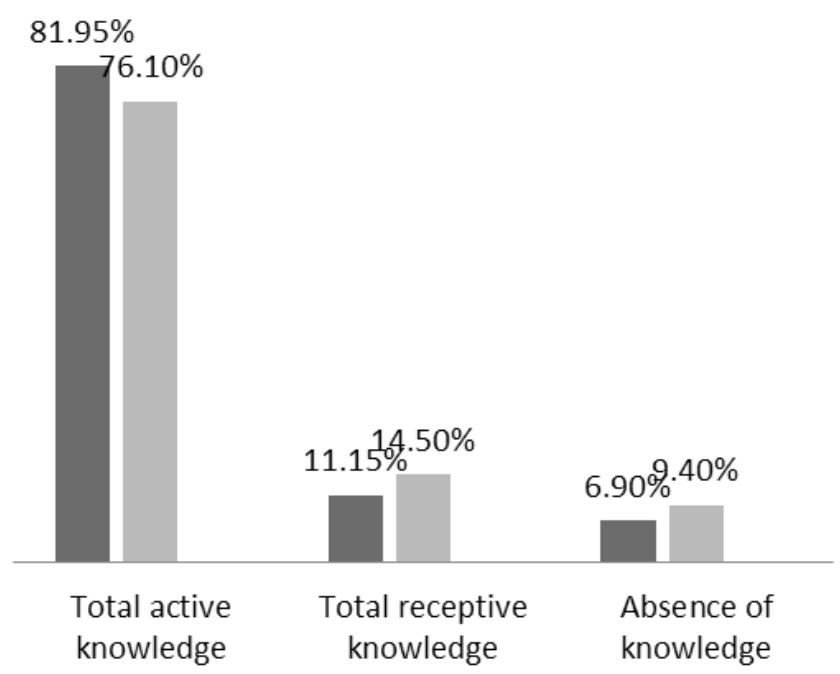

3rd grade students 
As could be observed in Graph 4, greater exposure of the second grade students during the second year of learning resulted in increase of the active knowledge of vocabulary from $54.9 \%$ to $76.10 \%$, making a total of $21.2 \%$ in favour of active knowledge. The receptive knowledge was reduced from $16.62 \%$ to $14.50 \%$, but the absolute absence of knowledge of a lexical item was reduced from $27.38 \%$ during the $2012 / 2013$ school year to only $9.40 \%$. In other words, $17.98 \%$ of unknown words at the end of the first year of learning were transferred to active or receptive fund of lexical competence during the second year of the educational process.

Based on the results from the second year of learning, an advance was also noticed with the third grade students. The active lexical fund in the second year of learning was $81.95 \%$ in comparison to $63.62 \%$ during the first year, which means that improvement of $18.33 \%$ was accomplished during one school year. The receptive fund was reduced linearly to $11.15 \%$ in comparison with the previous $16.15 \%$.

The receptive fund was reduced in favour of the active fund at both groups of students during the second year of the educational process of early learning of the Italian language as the second foreign language, but even more important was that the percentage of absolute absence of knowledge of lexical items was reduced in favour of the active and the receptive fund. Ignorance of lexicon was reduced from $19.78 \%$ to $6.90 \%$, which is the improvement of $12.88 \%$.

The difference between the students of the third grade and the second grade in the active fund during the second year of learning was reduced and amounted $4.85 \%$, while in the previous year was $8.72 \%$. Like in the first year, younger students during the second year accomplished better results in the receptive knowledge of lexicon for $0.47 \%$ in comparison to the students of the second grade, in the third grade the situation was better for $3.35 \%$ in favour of the students from the second grade.

The percentage of absolute ignorance was almost $8 \%$ higher for younger students during the research in 2011/2012. After a year, the discrepancy in knowledge between the students of the second and of the third grade was reduced and amounted $2.5 \%$.

The following conclusion is that both groups of students accomplished a significant progress in the development of the lexical competence during the second year of learning the Italian language as FL2. One of the factors 
surely is the increased fund of classes and the resulting exposure to TL and tested structures.

Another conclusion is that the younger students from both grades accomplished enviable results during the second year of learning, reducing the difference in knowledge between the two generations. During the second year of learning the Italian language as FL2, the results of the second grade students excelled the results accomplished by the third grade students during the 2011/2012. Based on this finding from our research, the conclusion is that the accomplished results speak in favour of levelling the knowledge of both groups of students, as well as in favour of the thesis "the sooner - the better".

We may conclude with certainty that both groups of students accomplished a significant improvement in development of lexical competence during the second year of learning the Italian language as FL2. One of the factors surely was the increased number of classes, resulting in longer exposure to TL and tested structures. Another conclusion is that the younger students in 2012/2013 accomplished enviable results due to longer exposure to TL, reducing the difference in knowledge in comparison with the older group of students.

After the analysis of the obtained results, gradation of lexical items have been made by ranking the most successfully adopted by both groups of examinees, by merging active and passive funds and assigning them to the category of knowledge (see Table 1).

Table 1. Gradation of lexical items and morphosyntactic structures according to the accomplishments of students in active and receptive knowledge.

\begin{tabular}{|l|l|c|}
\hline Rank & Lexical item & \% of adoption \\
\hline 1. & The first ten & 98.84 \\
\hline 2. & Acquaintance & 85.05 \\
\hline 3. & Introductions & 78.85 \\
\hline 4. & Colours & 78.84 \\
\hline 5. & Names of animals & 77.83 \\
\hline 6. & Subjects from surroundings & 77.71 \\
\hline 7. & Adjectives & 75.12 \\
\hline 8. & Family & 75.40 \\
\hline 9. & Names of toys & 73.80 \\
\hline 10. & School accessories & 73.29 \\
\hline 11. & Premises in house & 64.17 \\
\hline 12. & Christmas and New Year & 56.43 \\
\hline 13. & Birthday & 50.88 \\
\hline
\end{tabular}


Regardless of the exposure in some cases, as well as the frequency of certain words, younger students choose lexical items that are useful for them in given moment and these are stored firstly by phonological and semantic memory, either in vocabulary or in passive lexical fund.

We may conclude that the hypotheses "Lexical competence has certain role in defining success of early learning of two foreign languages in formal education" and "Exposure to FL2 levels differences in accomplishments between older and younger students" are completely confirmed on the basis of the presented results of 13 tasks presented to the students of the first and the second grade, i.e. the second and the third grade, comprising of 104 lexical items and with simple morphosyntactic structure.

\section{Conclusion}

All students of the first and the second grade, active participants of the research, originated from monolingual Serbian speaking families. After adopting the L1, 86\% of them had first linguistic experiences with learning a foreign language, most often by learning FL1 in pre-school education- $75 \%$ of the total number of students; attending private language schools was present at $12 \%$ of the students and private classes were present in $10 \%$ of cases. All examinees had chosen the English language as FL1, starting to learn it after as a compulsory subject in the first educational cycle. The selection of the English language as FL1 is not the characteristic of foreign language education only in Serbia, but also in other countries of the EU. This is the consequence of many factors, primarily because of the fact that the English language has become lingua franca.

Domination of the English language as FL1 since the eighties of the $20^{\text {th }}$ century lasts even today. As much as $89.9 \%$ of all the students from the first to the fourth grade learnt English as their first foreign language in Serbia in 2009. The range of another foreign languages that are introduced in the fifth grade, according to the data, is the following: German, French, Russian, Italian and Spanish. The main objection for the legislator is concerning the fund of foreign language classes in all three educational cycles, which are 72 classes on annual level. Since the learning occurs outside the linguistic communities to which the referred languages belong, it is 
necessary to make an improvement by greater exposure of students to the TL, between three and four classes weekly. Besides, the policy of plurilingualism and multiculturalism does not mean that only one- the English language - de facto is proclaimed for the compulsory subject that is taught in the first educational cycle. Without the wish to deny the importance of the English language as lingua franca, an effort should be made to give a chance to other languages to be taught in the first educational cycle.

Different trends in the European linguistic policy also have contributed to our orientation. Namely, in the first decade of this century, the issue of importance of creating a new linguistic policy in the spirit of cosmopolitism has been initialised by various European documents and action plans. Various projects within the EU have been initialised, with the main goal to introduce early learning of foreign languages into institutionalised frames. A "new" citizen of Europe will not be competitive in the market in any business area unless he or she speaks at least two foreign languages in addition to their mother tongue. It seems that the set goal is demanding, but only if the process of learning two foreign languages does not start at an early age, that is between six and ten.

At the very beginning of our paper, we mentioned the set goals and hypotheses. The first goal of the research was concerning the confirmation of the functionality of introducing the second foreign language in early age in primary school. However, a practical accomplishment of the referred goal resulted from this research. Excellent results accomplished at all tests of knowledge (Picasso dictation, lexical test) during the two years indicate that functionality of introducing two foreign languages in early age is not only possible, but also justified and reasonable. Our younger participants, the students of the first grade, during the first year of learning had somewhat less positive attitude toward FL2, as well as lower accomplishments at the lexical test in comparison to the older students, but during the next year they achieved the level of motivation and productive knowledge that remarkably exceeded the students of the second grade in the first year of learning. The obtained results assure us in the belief that FL2 should be introduced from the first grade, since in this way the period of exposure to TL is increased during both cycles of primary education.

Another goal of this research was directed to the critical analysis of the existing education of the Italian language. One might say that it is 
necessary to create educational process according to the age of students and, even more importantly, according to their interests. In the education designed in such a manner, motivation should not exist as a problem, but as the basis and springboard for successful learning of FL2, with simultaneous development of interculturalism. In order to accomplish the set goal, it is necessary to work on a professional and continuous improvement of teachers, who would modernise their didactical-methodical knowledge and implement it in the classroom. Since the age of examinees is very sensitive, a teacher should adapt goals, methods and techniques during the whole school year, without variations to the curriculum, in accordance with the climate and individual differences of the students in the class.

A conclusion is being imposed that a precondition for a successful teaching of foreign language at an early age is the prepared teacher as the facilitator of the process. In addition to the knowledge of FL and the culture at $\mathrm{C} 1$ level, a teacher must be familiar with characteristics of the age of students to whom he or she teaches, in order to adapt the teaching approach to individual needs of the group, but also of individuals, during the school year. It is important to point out that the student is a dominant figure, while the teacher needs to take over several roles within the classroom in order to create a favourable climate and establish relationships based on trust and equality. It is known that younger students learn by following a model, i.e. they imitate the older. Therefore, the responsibility of the teacher and the family is the key to success, both regarding the attitudes that students will create for FL2, belonging culture and nation, and the level of functional knowledge that they will achieve.

\section{References}

Brown, Douglas H. 1994. Teaching by Principles: An Interactive Approach to Language Pedagogy. Englewood Cliffs, NJ: Prentice Hall Regents. Bugarski, Ranko. 2003. Jezik i lingvistika. Beograd: Čigoja štampa.

Cushman, Penny, and Jackie Cowan. 2010. "Enhancing student self-worth in the primary school learning environment: Teachers' views and students' views." Pastoral Care in Education 28 (2): 81-95.

Filipović, Jelena. 2009. Moć reči. Beograd: Zadužbina Andrejević. 
Filipović, Jelena, Julijana Vučo, and Ljiljana Djurić. 2007. “Critical Review of Language Education Policies in Compulsory Primary and Secondary Education in Serbia.”. Current Issues in Language Planning 8 (2): 222-242.

Vučo, Julijana. 2005. "Istituzioni e l'insegnamento di lingue straniere. Verso una politica linguistica europea." In Lingue, istituzioni, territori. Riflessioni teoriche, proposte metodologiche ed esperienze di politica linguistica, edited by Cristina Guardiano, Emilia Calaresu, Cecilia Robustelli, and Augusto Carli, 435-447. Roma: Bulzoni.

Vučo, Julijana. 2010. „Interkulturalnost kao okvir i kontekst komunikativne nastave stranih jezika u ranom uzrastu"Inovacije u nastavi 23: 53-61. Beograd: Učiteljski fakultet.

Vučo, Julijana (Вучо, Јулијана). 2013. «О неким специфичностима интеркултурне размене у савременој настави страних језика.» In Језищи и кулииуре у времену и иростиору, вол. 1, уредиле Снежана Гудурић и Марија Стефановић, 373-380. Нови Сад: Филозофски факултет.

Šuvakovic, Aleksandra. 2014. „Usvajanje dva strana jezika u ranom uzrastu u kontekstu evropske politike plurilingvizma - studija slučaja“"In Uloga obrazovanja i vaspitanja u razvijanju humanističkih interkulturalnih i nacionalnih vrednosti, uredili Branko Jovanović i Mladen Vilotijevic, 983-1011. Kosovska Mitrovica: Filozofski fakultet Univerziteta u Prištini; Beograd: Srpska akademija obrazovanja. 


\title{
Aleksandra Šuvaković
}

\section{PRIMERI DOBRE PRAKSE U OBLASTI RANOG I POČETNOG UČENJA STRANIH JEZIKA U FORMALNOM OBRAZOVANJU}

\begin{abstract}
Sažetak
Početak XXI veka sa sobom donosi novine u jezičkom planiranju i programiranju unutar Evrope čime se u prvi plan stavlja potreba da se pored maternjeg ovlada znanjem još dva strana jezika. Tako postavljen cilj nije lako ostvariv osim ukoliko se u proces učenja stranih jezika ne uđe u periodu ranog detinjstva. U ovom radu ćemo predstaviti deo rezultata dvogodišnjeg empirijskog istraživanja sprovedenog primenom metode studija slučaja, na uzorku od šezdeset učenika osnovne škole. Uzorak čine učenici prvog i drugog razreda (prva godina učenja drugog stranog jezika), odnosno drugog i trećeg razreda (druga godina učenja drugog stranog jezika). Na osnovu merenja leksičke kompetencije koja je određujuća za utvrđivanje uspešnosti procesa ranog učenja dva strana jezika u formalnom obrazovanju doći ćemo do zaključaka u vezi sa funkcionalnošću uvođenja dva strana jezika u prvom obrazovnom ciklusu. Sagledaćemo da li i u kojoj meri postoje razlike između starijih i mlađih učenika kao i da li se one, ukoliko postoje, nivelišu dužom izloženošću novom jezičkom prilivu, odnosno da li je jednaka razlika, ukoliko je ima, i tokom prve i tokom druge istraživačke godine. Leksičke jedinice ćemo podeliti po domenima čime ćemo utvrditi u kojoj meri učenici lakše usvajaju leksiku koja je predmet njihovog interesovanja i obrnuto.
\end{abstract} cija.

Ključne reči: učenici, uzrast, rano učenje, drugi strani jezik, leksička kompeten- 